\title{
Structural Equation Model of Customer Loyalty: Case Study of Traditional Retail Shop Customers in Hatyai District, Songkhla Province, Thailand
}

\author{
Anuwat Songsom (Corresponding author) \\ Faculty of Management Sciences, Prince of Songkla University \\ Hatyai Campus, Songkhla, Thailand \\ E-mail: sanuwat52@gmail.com \\ Charlee Trichun \\ Faculty of Management Sciences, Prince of Songkla University \\ Hatyai Campus, Songkhla, Thailand \\ E-mail: Charlee.t@psu.ac.th
}

Received: Nov. 30, 2012 Accepted: December 20, 2012 Published: January 1, 2013

doi:10.5296/jmr.v5i1.2782 URL: http://dx.doi.org/10.5296/jmr.v5i1.2782

\begin{abstract}
This research aimed to develop a structural equation model of customer loyalty to traditional retail shop in Hat Yai district, Songkhla province. The sample consisted of 500 cases of multi-stage sampling. Data was significantly statistical analyzed by using LISREL program. The results indicated the developed model was valid and fitted to empirical data. The factors of CSR expectation, switching cost, customer satisfaction and customer trust were significantly and positively related to customer loyalty. Customer trust factor was the highest direct effect on customer loyalty while customer satisfaction was the highest indirect effect. A clear understanding of the postulated relationships among the studied variables might encourage the traditional retail shop to figure out appropriate course of action to win customers' trust by providing better services in order to create a loyal customer base.
\end{abstract}

Keywords: Customer loyalty, Traditional retail shop, Structural equation model 


\section{Introduction}

Several aspects of customer loyalty have been of interest in marketing research. Businesses have admitted that customer loyalty plays an important role in adding value to their business. Furthermore, building loyalty among old customers costs much less than making new ones. Most importantly, customer loyalty has a direct influence on the word of mouth advertisement for the business (Brown et al., 2005; Lewis \& Soureli, 2006). Customer loyalty helps enlarge premium price sales (Reichheldl, 1996), market share (Chaudhuri \& Holbrook, 2001) and profitability for the business (Chiou \& Droge, 2006). Customer loyalty is regarded as necessary for successful competition in all types of businesses: manufacturers, services and retailers (Dick \& Basu, 1994).

However, consumer behaviors have been changed a great deal due to the customers' own values, together with the social development and marketing processes. Most of local traditional retail shops which used to provide all types of consumer products are now confronting a tough and threatening competition by the modern trade malls and hypermarts which are growing rapidly and penetrating in even small neighborhoods.

Hat Yai District in Songkhla Province is one area among several others in Thailand that have been invaded by the rapidly growing modern trade retailing businesses: convenience stores and hypermarts. The new retailing businesses are beating the traditional local retail shops in all competitive aspects: benefits, total sales and number of customers. These traditional retail shops are, by nature, less privileged in sales competition: in capital, shop displays or decorations, services, technology and administration and management (Paopongsakorn, 2002). It is important that these local traditional retail shops carry out certain business strategies to keep their old customers. They must be knowledgeable in the strategic plans to generate customer loyalty, better marketing procedure and fair competition.

This study was to investigate factors that are contributing to customer loyalty among the local traditional retail shops. It aimed specifically to build up the Structural Equation Model (SEM) for customer loyalty. The SEM consisted of latent variables and observable variables that demonstrate both direct and indirect effects toward customer loyalty. These factors will therefore be utilized among the local traditional retail shops to secure and develop their business and at the same time, to better satisfy the customers in their community.

\section{Literature Review}

Literature reviews found the analysis variables in terms of theory to investigate the factors expected to affect customer loyalty in this research is divided into two groups. Firstly, this is the contemporary factor originating in the adjustment of marketing paradigms and competitive environments of present retail business. This composed of corporate social responsibility (CSR) and switching cost. Secondly, this is regarded as traditional component which is the external or internal factors of the consumers affecting the customer loyalty, which are, perceived service quality, customer satisfaction and customer trust.

\subsection{CSR Expectation}

CSR activities can range from simple philanthropic involvement such as charitable 
contributions to more strategically designed philanthropy, cause-related marketing and green marketing (Poolthong \& Mandhachitara, 2009). Marketing studies found that CSR can positively affect consumer's attitudes towards the firm and its products. Positive consequences reported are, for example, perceived service quality (Eskildsen \& Kristensen, 2008; Lee \& Bellman, 2008; Pooltong, 2008; Yu et al., 2005), customer satisfaction (Campo \& Yague, 2009; Eskildsen \& Kristensen, 2008; Lee \& Bellman, 2008; Xueming \& Bhattacharya, 2006), and customer trust (Castaldo, 2009; Pavlos et al., 2009; Pooltong, 2008) Therefore, the following relationships are hypothesized for empirical testing:

H1: CSR expectation is positively related to perceived service quality

$\mathrm{H} 2$ : CSR expectation is positively related to customer satisfaction

H3: CSR expectation is positively related to customer trust

CSR expectation is measured by four dimensions; fairness business, customer responsibility, expectation on community development and expectation on environmental care. These are originated by the conceptual integration of Pooltong (2008) and Corporate Social Responsibility Institute (2009).

\subsection{Switching Cost}

Switching costs can be defined as the costs involved in changing from one shop to another. Part of switching costs may involve loyalty benefits that have to be given up by a customer when his or her relationship with the firm ends. The customer will be motivated to stay in existing relationships to economize on switching costs, such as the transaction-specific investments that the customer has made on the relationships. The establishment of new relationship represents some sort of investment of effort, money, and time. (Lam et al., 2004). Consistent with these arguments, the past research found that for the purchase of goods and services, customers are less likely in both the consideration and select new service provider (Chou \& Lu, 2009; Lam et al., 2004; Tsai et al., 2010; Zeng \& Zhang, 2008). This leads us to advance the following hypothesis:

H4: Switching cost is positively related to customer loyalty

Switching cost is measured by integration from the concept of Lam et al. (2002) by measuring from three dimensions; cost of increased expense, time waste and difficulty of finding information as well as related technological learning.

\subsection{Perceived Service Quality}

Service quality is the delivery of excellent or superior service relative to customer expectation. The customer perception of service quality stems from a comparision of what they feel service firms should offer, with their perceptions of the actual performance. Correspondingly, the empirical study of Bourdeau (2005), has revealed that satisfaction can be predicted by the service performance perceived by customers. This result was buttressed by the findings of other researchers (e.g. Chao et al., 2009; Vigripat, 2008; Yieh et al., 2007). In addition, service quality enhances customers' inclination to buy again, to buy more, to buy other services, to become less price-sensitive and to tell others about their favorable experiences (Bourdeau, 2005; Chou \& Lu, 2009; David, 2007; Pooltong, 2008; Vigripat, 
2008). Therefore, it is proposed that:

H5: Perceived service quality is positively related to customer satisfaction

H6: Perceived service quality is positively related to customer trust

H7: Perceived service quality is positively related to customer loyalty

Perceived service quality; the researcher used the concept of Parasuraman, Zeithaml and Berry (1998) measured by five dimensions; tangible reliability, responsive, assurance and empathy.

\subsection{Customer Satisfaction}

In service business, a high level of contact between service providers and customers is required. The greater customer satisfaction with their service experience, the more they feel they can trust both the organization itself and the personnel that provide its service. Thus, satisfied customers are more likely to increased use on short and in the long run by building trust of an organization than are dissatisfied customers (Yieh et al., 2007). Kantsperger \& Kunz's (2010) empirical findings also supported this argument. In addition, several authors have found a positive correlation between customer satisfaction and loyalty (Akbar \& Pavez, 2009; Bourdeau, 2005; Castaldo, 2009). For the reasons given above, we propose the following hypothesis:

H8: Customer satisfaction is positively related to customer trust

H9: Customer satisfaction is positively related to customer loyalty

Customer satisfaction is measured by various methods integrated by the various concepts of persons, which is Lam et al. (2002) by particularly selecting dimensions not redundant with the dimensions of perceived service quality. This research is measured the satisfaction in five dimensions; satisfaction by variety of products, price satisfaction, location or physical aspects of the store, service providers and marketing promotion

\subsection{Customer Trust}

Trust plays a major role in managing the service companies. From a customer perspective, trust becomes crucial in many relational exchange situations and reduces the perceived risk of the service outcome (Kantsperger \& Kunz, 2010). Trust is logically and experientially a critical variable in relationships, as the marketing literature shows. This variable is based on past behaviors but it shapes the future. Trust is often considered as the most crucial element to a successful relationship. Empirical research has revealed that the presence of trust will have a positive effect on the continuity of a transactional relationship. Studies taking service industries as their subject have verified that trust is positively related to customers' word-of-mouth behavior (Yieh et al., 2007). This leads us to advance the following hypothesis:

H10: Customer trust is positively related to customer loyalty

Customer trust; in order not to let the measurement dimension and question items repeatedly with the measurement of other latent variables including perceived service quality and customer satisfaction, the researcher considered to use the concept of Pooltong (2008) measured by two dimensions, which is benevolence and creditability. 


\section{Macrothink

As a result, this study determined the hypothesis of ten items and developed into proposed conceptual model of factors affecting the customer loyalty as the figure 1. According to the measurement of latent variables in the model which include two exogenous variables, which are CSR-expectations and switching costs, and four endogenous variables, which are perceived service quality, customer satisfaction, customer trust, and customer loyalty.

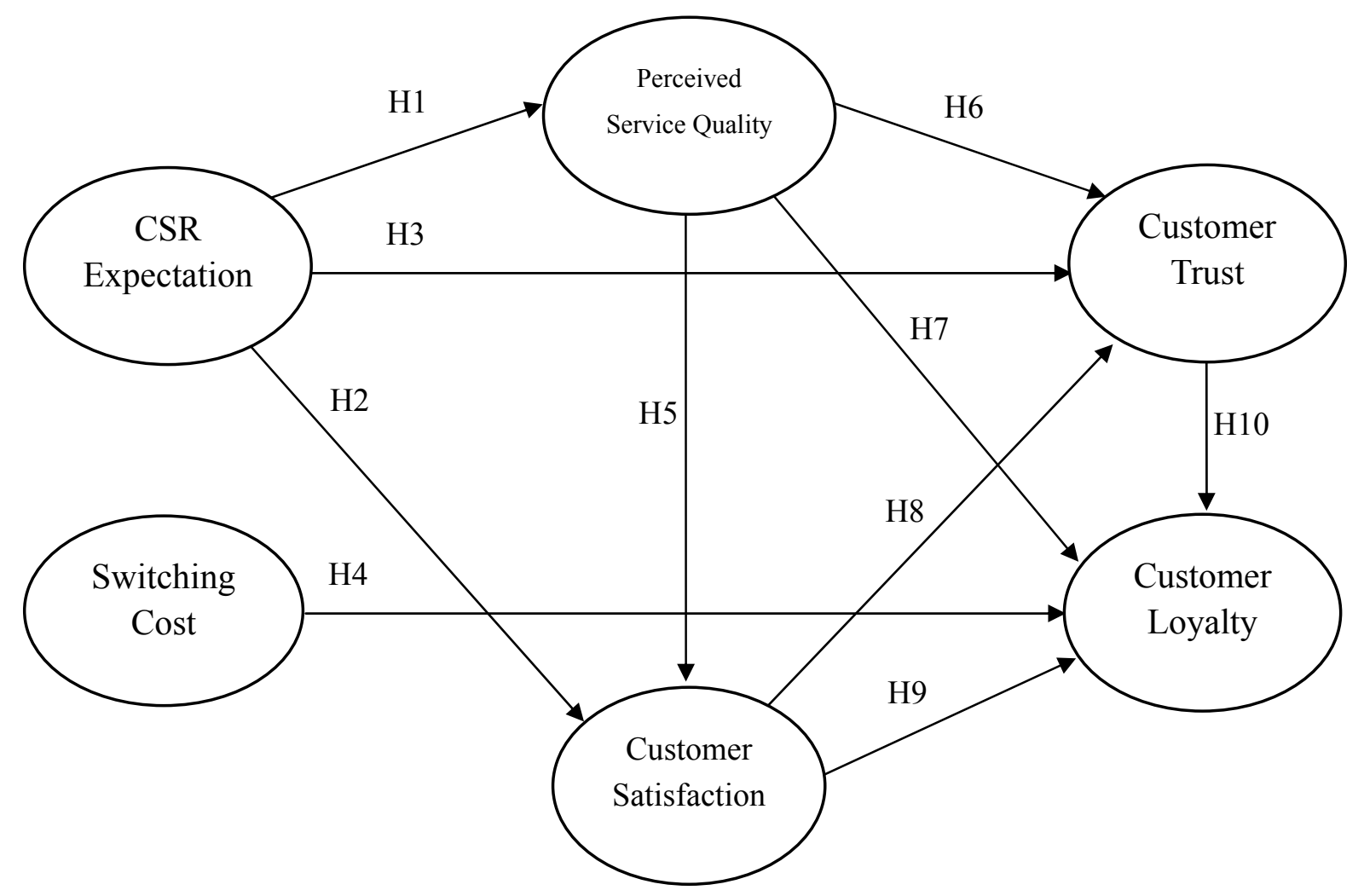

Figure 1. Conceptual Model of Factors Affecting the Customer Loyalty

\section{Research Methodology}

The samples of the present study were 500 customers of the local grocery shops in Hat Yai District, Songkhla Province. This number was calculated from the ratio of 20 research samples per one observable variable of the study (Lindeman, Merenda \& Gold, 1980), and 5-10 samples were included for each approximate parameter (Hair, Anderson, Tatham \& Black, 1998). The Multi-Stage Sampling was then employed to select the research samples. At the first stage the stratified sampling method was applied. All Sub-districts in Hat Yai District were divided into two groups. The first group included Hat Yai Sub-district and its neighboring Sub-districts, and the other group included other outskirt Sub-districts. Next, the quota sampling method was used to select two Sub-districts from each of the two groups. This resulted in four Sub-districts of Hat Yai, Kuan Lang, Tha kham and Phatong. One hundred and twenty five research samples were finally purposively selected from these four Sub-districts making the sample size of 500 .

The research instrument was Likert's five-rating scales questionnaires asking for personal 
information of the samples and information about the indirect and observable variables. The questionnaires were validated for content validity using the Item-Objective Congruence (IOC) evaluated by five experts in the area. The questionnaire items with the IOC higher than 0.60 were included. The questionnaires were then piloted with 60 customers of the local traditional retail shops in Muang District, Songkhla Province. The reliability of the questionnaire was analyzed using the Cronbach's Alpha Coefficient. Results showed that the reliability of all items was in the range of $0.6447-0.9016$ and the total reliability of the questionnaire was 0.9727. The construct validity of the instrument in measuring the latent variables was measured using the Bartlette's Test of Sphericity and the Kaiser-Meyer-Olkin Measurement of Sampling Adequacy (KMO). Results showed that the Bartlette's test was found at a significant level. This means that the matrix correlation coefficient is not a unique matrix. While the KMO index was found at 0.500-0.881, showing that the obtained data were suitable for calculating factor analysis. The researcher then performed the Confirmatory Factor Analysis (CFA) to test the linear correlation of the constructed model using the LISREL software to test the compatibility of the constructed model and empirical data.

\section{Results}

Results concerning the research samples revealed that most of the research samples $(58 \%)$ were female, most were at the age range 18-22 (29.6\%), and most were university graduates (58.2\%). Most were private business employees (38.4\%). Most had a monthly salary at the range of 10,001-15,000 baht (32.0\%). Regarding the customers' buying behaviors, it was found that most of the research samples bought goods at the local traditional retail shops on average 3 times a month (37.4\%). Most paid 51-100 baht in each purchase and service of the retail shops $(43.2 \%)$.

The Structural Equation Model (SEM), also known as the "Causal Model of Customer Loyalty" for the traditional retail shops was revised within the acceptable standard errors range and the compatibility of the observable data within the Chi-square rate at 488.17 at degree of freedom (df) of 246. The proportion of Chi-square and the d.f was $1.98, \mathrm{GFI}=0.93$, $\mathrm{AGFI}=0.90, \mathrm{CFI}=0.99, \mathrm{RMR}=0.018, \mathrm{RMSEA}=0.044$ and $\mathrm{CN}=312.57$. This shows that the factors of CSR expectation, switching cost, customer satisfaction and customer trust can be used to describe $74 \%$ of the variance of customer loyalty.

Results of the analysis of direct effects of the latent variables in the SEM comply with the research hypothesis (except H5 and H6). This therefore can be concluded that the customers' CSR expectation had a direct effect on their perception of the quality of the services at the significant level 0.01 and had a direct effect on customer satisfaction and trust at the significant level 0.05 . The perception of quality of services had a direct effect on the customer satisfaction at 0.01 , while the customer's trust and the switching cost have direct effect on customer loyalty at the level 0.01 (See Table 1). 
Table 1. Standardized Direct Effects, Indirect Effects, and Total Effects of the study variables

\begin{tabular}{|c|c|c|c|c|c|c|c|}
\hline Variables & $\overline{\mathrm{R}^{2}}$ & Effect & $\begin{array}{c}\text { CSR } \\
\text { Expectation }\end{array}$ & $\begin{array}{l}\text { Switching } \\
\text { Cost }\end{array}$ & $\begin{array}{l}\text { Perceived } \\
\text { Service } \\
\text { Quality }\end{array}$ & $\begin{array}{c}\text { Customer } \\
\text { Satisfaction }\end{array}$ & $\begin{array}{c}\text { Customer } \\
\text { Trust }\end{array}$ \\
\hline $\begin{array}{l}\text { Perceived } \\
\text { Service } \\
\text { Quality }\end{array}$ & 0.85 & $\begin{array}{l}\text { Direct Effect } \\
\text { Indirect Effect } \\
\text { Total Effect }\end{array}$ & $\begin{array}{c}0.93^{* * *} \\
- \\
0.93^{* * *}\end{array}$ & $\begin{array}{l}- \\
- \\
-\end{array}$ & $\begin{array}{l}- \\
- \\
-\end{array}$ & $\begin{array}{l}- \\
- \\
-\end{array}$ & $\begin{array}{l}- \\
- \\
-\end{array}$ \\
\hline $\begin{array}{l}\text { Customer } \\
\text { Satisfaction }\end{array}$ & 0.76 & $\begin{array}{l}\text { Direct Effect } \\
\text { Indirect Effect } \\
\text { Total Effect }\end{array}$ & $\begin{array}{l}0.11^{* *} \\
0.70^{* * *} \\
0.81^{* * *}\end{array}$ & $\begin{array}{l}- \\
- \\
-\end{array}$ & $\begin{array}{l}0.75^{* * *} \\
- \\
0.75^{* * *}\end{array}$ & $\begin{array}{l}- \\
- \\
-\end{array}$ & $\begin{array}{l}- \\
- \\
-\end{array}$ \\
\hline $\begin{array}{l}\text { Customer } \\
\text { Trust }\end{array}$ & 0.89 & $\begin{array}{l}\text { Direct Effect } \\
\text { Indirect Effect } \\
\text { Total Effect }\end{array}$ & $\begin{array}{l}0.35^{* *} \\
0.47^{* * *} \\
0.82^{* * *}\end{array}$ & $\begin{array}{l}- \\
- \\
-\end{array}$ & $\begin{array}{l}-0.34^{* *} \\
0.73^{* * *} \\
0.39^{* *}\end{array}$ & $\begin{array}{c}0.97^{* * *} \\
- \\
0.97^{* * *}\end{array}$ & $\begin{array}{l}- \\
- \\
-\end{array}$ \\
\hline $\begin{array}{l}\text { Customer } \\
\text { Loyalty }\end{array}$ & 0.74 & $\begin{array}{l}\text { Direct Effect } \\
\text { Indirect Effect } \\
\text { Total Effect }\end{array}$ & $\begin{array}{c}- \\
0.35^{* * *} \\
0.35^{* * *}\end{array}$ & $\begin{array}{c}0.57^{* * *} \\
- \\
0.57^{* * *}\end{array}$ & $\begin{array}{l}-0.25 \\
0.30 \\
0.05\end{array}$ & $\begin{array}{l}0.07^{* * *} \\
0.62^{* * *} \\
0.69^{* * *}\end{array}$ & $\begin{array}{c}0.64^{* * *} \\
- \\
0.64^{* * *}\end{array}$ \\
\hline $\begin{array}{l}\chi^{2}=488.17 \\
\text { AGFI }=0.90\end{array}$ & & $\begin{array}{l}\mathrm{df}=246 \\
\mathrm{RMSEA}=0.044\end{array}$ & \multicolumn{2}{|c|}{$p=0.00000$} & \multicolumn{3}{|c|}{ GFI $=0.93$} \\
\hline
\end{tabular}

** Significant at the 0.05 level, *** Significant at the 0.01 level

\section{Conclusion and Discussion}

The Structural Equation Model (SEM) or "Causal Model of Customer Loyalty" for the local traditional retail shops showed that the factors on trust and switching cost had a direct effect on customer loyalty to the traditional retail shops. If the customers trust and believe in the services of the retail shop, they will have an intention to buy goods or use the services of the shops. This is known as the attitudinal loyalty. Positive attitude towards the local traditional retail shops can affect the customer behaviors in the forms of repurchase rate and word of mouth advertisement about the retail shops. Similarly, the switching cost including waste of time, loss of certainty in getting the products and waste of time in finding information about the new retail shops are contributing factors to customer loyalty to the same retail shops. These findings are in congruence with the Theory of Reasoned Action and Theory of Planned Behavior which explain that both the presence and absence of any customer behaviors are always voluntary and logical.

The finding showed the customers' perceived service quality had no direct effect on their loyalty and it had direct negative effect on customer trust did not conform to the hypothesized proposal. This can be explained by the fact that quality of services was evaluated by the customers in comparison to their desired service, adequate service and zone of tolerance. The quality of services of the local traditional retail shops was at a low level in the customers' perception in comparison to the services given at the modern trade superstores or hypermarts, likewise the study of Paopongsakorn (2002). 
The customer satisfaction was found that both direct and indirect positive affected on customer loyalty as the study of Zeng \& Zhang (2008). Moreover, the indirect effect was passed through the consumer trust in the service. It was explained that customer satisfaction vary, and customers usually develop from their former trust to expectations as to what will happen or what service they will receive before they make a decision to use the services or buy the products. The consumer satisfaction after the purchases or services was the result of an evaluation of the expectations and the services or purchases they had. It is important that successful marketers bridge the gap between the customer expectations and product actions. This can be done by building customer satisfaction through other offering or services that are beyond their expectations before the purchases and this will in turn influence customer loyalty. In this way the customer satisfaction will directly effect their loyalty to the retail shops. On the other hand, it was found that customer satisfaction has an indirect influence through the customer trust on their loyalty. This can be explained by the fact that there is a gap between customer expectation and the real services they get. The businesses must try to narrow the gap between the two factors or to build up the trust of the customers and they will be loyal to the products or the services and the business respectively.

The factor of customer expectation on the CSR activities was found to have indirect effect on customer loyalty through the factors of perceived service quality, satisfaction and trust. This can be explained by the fact that the customer expectations of the retail shops have included not only their services but also their contributions to the society. These expectations have direct $e$ on perception of quality of product and services and value and appraisal of the business. If the local traditional retail businesses can respond to these customer expectations, they will feel satisfied and this brings about their trust and loyalty, respectively, to the retail shops. This finding conformed to Yu et al. (2005) and the American Customer Satisfaction Index (ACSI) that was developed as the measuring instrument to evaluate the customer satisfaction at the macro scale of the whole country. This index was developed to reflect proficiency of both the industrial organizations and the country capacity as a whole. The ACSI model showed that the quality and value of the products or services and the customer expectation will have contributing effects on the customer satisfaction, and the customer satisfaction in turn will positively influence the customer loyalty to the products and services. On the other hand, if the customers are not satisfied with the products, this will negatively affect the business or it can lead to customer complaints.

The influences of expectation, perceived product quality, satisfaction and trust of the customers are psychological factors related to attitudes of customers and they can bring about customer loyalty in terms of repurchasing and telling others about the business (word of mouth). It is therefore recommended that the marketers in local traditional retail shops should narrow the gap between customer expectations and the real service they get. In the mean time, they need to strengthen the awareness among the customers of the loss of prospects in both costs and time if they want to use the services of other or new retail shops.

\section{References}

Blackwell, R., Miniard, P. W., \& Engel, J. F. (2006).Consumer behavior (10 ${ }^{\text {th }}$ ed.). Columbus, 
$\mathrm{OH}$ : Thomson South-Western.

Bourdeau, L. B. (2005). A new examination of service loyalty: Identification of the antecedents and outcomes of additional loyalty framework. Doctoral Thesis, Florida University. Gainesville, Florida.

Brown, T. J., Thomas, E. B., Dacin, P. A., \& Richard, F. G. (2005). Spreading the word: Investing antecedents of consumers' positive Word-of-Mouth intentions and behaviors in a retailing context. Journal of the Academy of Marketing Science, 33(2), 123-138. http://dx.doi.org/10.1177/0092070304268417

Chao, Y., Lee, G. Y., \& Ho, Y. C. (2009). Customer loyalty in virtual environments: An empirical study in e-bank. Journal of Computational Methods in Science and Engineering, 48(2), 497-500. http://dx.doi.org/10.1063/1.3225357

Chaudhuri, A., and Holbrook, M. B. (2001). The chain of effects from brand trust and brand affect to brand performance: The role of brand loyalty. Journal of Marketing, 65(April), 81-93. http://dx.doi.org/10.1509/jmkg.65.2.81.18255

Chiou, J. S., \& Droge, C. (2006). Service quality, trust, specific asset investment, and expertise: direct and indirect effects in a satisfaction- loyalty framework. Journal of the Academy of Marketing Science, 34(4), 613-627. http://dx.doi.org/10.1177/0092070306286934

Corporate Social Responsibility Institute. (2009). CSR guidelines. Bangkok, Thailand: Icon Printing.

Dick, A., and Basu, K. (1994). Customer loyalty: Toward an integrated conceptual framework. Journal of the Academy of Marketing Science, 37(2), 170-180. http://dx.doi.org/10.1177/0092070394222001

Hair, J. F., Anderson, R. E., Tatham, R. L., \& Black, W. C. (1998). Multivariate Data Analysis. $5^{\text {th }}$ Edition. Upper Saddle River, NJ: Prentice Hall.

Islam, M. S. (2008). The analysis of customer loyalty in Bangladeshi mobile phone operator industry. Independent Business Review, 1(January), 1-15.

Kotler, P., \& Keller, K. L. (2009). Marketing management. (13 ${ }^{\text {th }}$ ed.). Upper Saddle River, NJ: Pearson Education International.

Lam, S.Y., Shanker, V., Erramili, M.K.,\& Musthy, B. (2002). Customer value, satisfaction, loyalty, and switching costs: An illustration from business-to-business service context. Journal of the Academy of Marketing Science, 32(3), 293-311. http://dx.doi.org/10.1177/0092070304263330

Lewis, B. R., \& Soureli, M. (2006). The antecedents of consumer loyalty in retail banking. Journal of Consumer Behavior, 5(2), 15-31. http://dx.doi.org/10.1002/cb.46

Lindeman, R. H., Merenda, P. F., \& Gold, R. Z. (1980). Introduction to bivariate and 
multivariate analysis. Illinois: Scott, Foresman and Company.

Oliver, R. L. (1999). Whence consumer loyalty. Journal of Marketing, 63(Special Issue), 33-44. http://dx.doi.org/10.2307/1252099

Parasuraman, A., Zeithaml, V. A., \& Berry, L. L. (1998). A conceptual model of service quality and its implications for future research. Journal of Marketing, 49(1), 41-50. http://dx.doi.org/10.2307/1251430

Paopongsakorn, N. (2002). The Retail Business in Thailand: Impact of the Large Multinational Corporation Retailers. A Research Report Submitted to Thailand Development Research Institute.

Pavlos, A. V., Argiris, T., Adam, P. V., \& Panagiotis, K. A. (2009). Corporate social responsibility: Attributions, loyalty, and the mediating role of trust. Journal of the Academy of Marketing Science, 37(2), 170-180. http://dx.doi.org/10.1007/s11747-008-0117-x

Pooltong, Y. (2008). Customer Loyalty: The Role of CSR, Customer-Company Identification and Service Quality. Ph.D. Dissertation, Thammasat University.

Reicheheld, F. F. (1996). The Loyalty Effect: The Hidden Force Behind Growth, Profits, and Lasting Value. Boston: Harvard Business School Press.

Schiffman, L. G., \& Kanuk, L. L. (2007). Consumer behavior. $\left(9^{\text {th }}\right.$ ed.). Upper Saddle River, NJ: Pearson Education.

Solomon, M. (2009). Consumer behavior: Buying, having, and being ( $8^{\text {th }}$ ed.). Upper Saddle River, NJ: Pearson Education.

Sundel, M., \& Sundel, S. (2004). Behavior change in the human services. (5 $5^{\text {th }}$ ed.). Thousand Oaks, CA: Sage.

Vigripat, T. (2008). Analysis of Antecedents of Customer Loyalty and an Examination of Switching Costs as a Moderator Variable: A Study of the Mobile Phone Service Marketing in Thailand. Ph.D. Dissertation, Ramkhamhaeng University.

Yu, C. M., Wu, L. Y., Chiao, Y. C., \& Tai, H. S. 2005. Perceived quality, customer satisfaction, and customer loyalty: The case of Lexus in Taiwan. Journal of Total Quality Management, 16(6), 707-719. http://dx.doi.org/10.1080/14783360500077393

Zeng, Y., \& Zhang, L. (2008). An empirical study on the relationship among customer satisfaction, switching cost and store loyalty. Journal of Chinese Marketing, 1(April), 25-31.

\section{Copyright Disclaimer}

Copyright reserved by the author(s).

This article is an open-access article distributed under the terms and conditions of the Creative Commons Attribution license (http://creativecommons.org/licenses/by/3.0/). 